\title{
Erratum: EspL is a bacterial cysteine protease effector that cleaves RHIM proteins to block necroptosis and inflammation
}

Jaclyn S. Pearson, Cristina Giogha, Sabrina Mühlen, Ueli Nachbur, Chi L. L. Pham, Ying Zhang, Joanne M. Hildebrand, Clare V. Oates, Tania Wong Fok Lung, Danielle Ingle, Laura F. Dagley, Aleksandra Bankovacki, Emma J. Petrie,

Gunnar N. Schroeder, Valerie F. Crepin, Gad Frankel, Seth L. Masters, James Vince, James M. Murphy, Margaret Sunde,

Andrew I. Webb, John Silke and Elizabeth L. Hartland

Nature Microbiology 2, 16258 (2017); published online 13 January 2017; corrected 13 February 2017

In the original HTML version of this Letter, the author information appeared incorrectly. Jaclyn S. Pearson and Cristina Giogha contributed equally to this work. Two co-authors have present addresses: Department of Molecular Infection Biology, Helmholtz-Centre for Infection Research, 38124 Braunschweig, Germany (Sabrina Mühlen); and Centre for Experimental Medicine, Queen's University Belfast, BT9 7BL, UK (Gunnar N. Schroeder). This information has been corrected. 